TID-4500, UC-41

Heaith and Safety

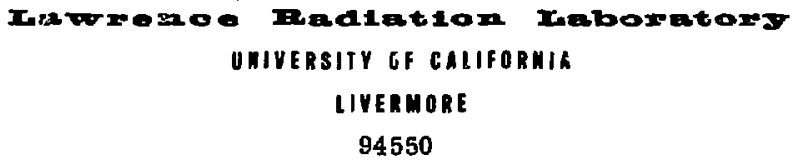

TJCRL-51093

SEMIANNUAL REPORT OF ENVIRONMENTAL LEVELS

OF RADIOACTIVITY IN THE VICINITY OF THE

LAWRENCE LIVERMORE LABORATORY

JANUARY THROUGH JUNE 1971

P. H. Gudiksen

MS. Date: July 12, 1971 


\section{Foreword}

This report was prepared for submission to the U.S. Atomic Energy Commission by the Environmental Evaluation Section of the Hazards Control Department at the Lawrence Livermore Laboratory. The analyses of the sampies were pexformed by various groupd within the Laboratory, such as the Hazards Control Department Analytical and Radiation Counting Laboratories, the Radiochemistry Department, and the Bio-Medical Division. Data were also obtained from reliable outside sources.

This roport wat prepered as in eccount of wark groneorcd by the Unlied States Govermment. Moithor the Unitad Stales nor the United states Atomic Enervy Commition, nor any of thetr employes, nor any of thet sontractom, cubcontractors, or thol omployes, makes any womenty, expres or inplied, or acumes en; lept libility or responsibility for the acsurtey, cortpletenes of uefolinese of any informatton, apparatus, moduct or froces dieclosed, or represents that its use would not lnfringe privately owned rishte. 


\section{Contents}

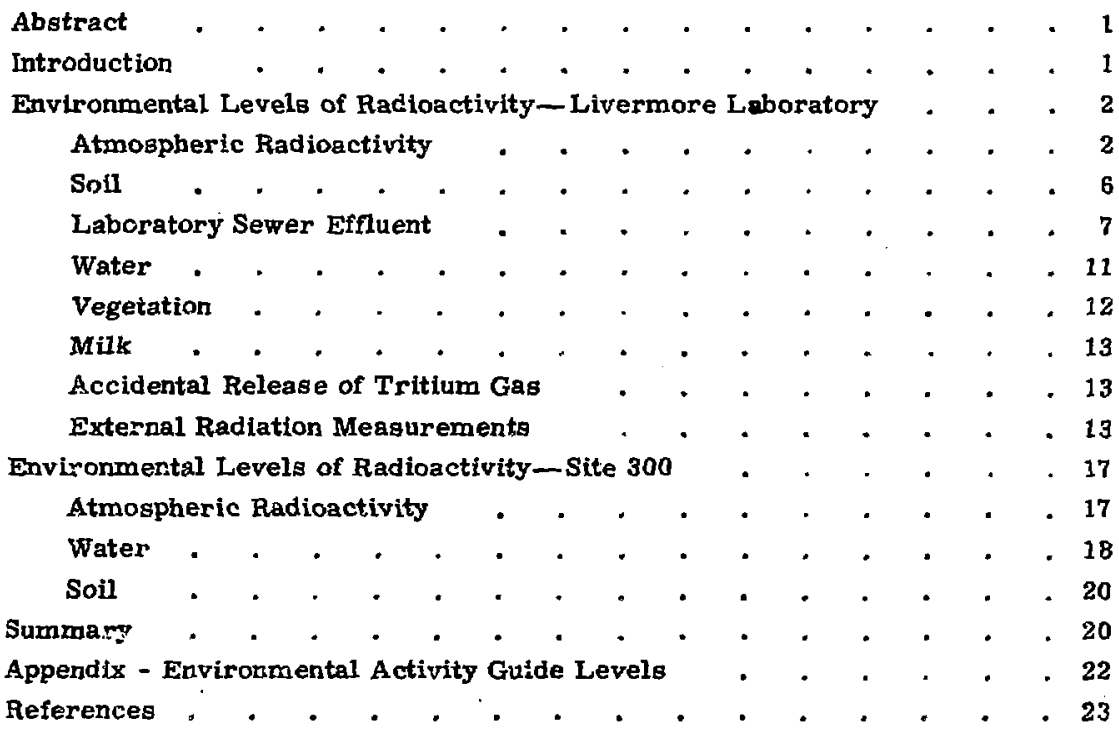




\title{
SEMIANNUAL REPORT \\ OF ENVIRONMENTAL LEVELS OF RADIOACTIVITY IN THE VICINITY OF THE \\ LAWRENCE LIVERMORE LABORATORY \\ JANUARY THROUGH JUNE 1971
}

\begin{abstract}
An environmental gurveillance program was conducted within the Livermore Valley and Site 300 areas to determine the effect of the Lawrence Livermore Laboratory operations on the surrounding environment. Analyses for gross radioactivity and for specific radionuclides of interest in a variety of environmental samples were perforined. The results of these analyses are provided in the report.

Air particulates, soil, watar, and sewage samples ahowed similar gross radioactivities to those measured during

the past year. Gamma spectral measurements of on-site airborne particulates revealed detectable activities of the tyoical gamma emitters observed in global fallout. Isotopic urantum analyses of particulates collected on air filters at Site 300 indicate the uranium in the particulates was depleted in ${ }^{235} \mathrm{U}$ with respect to that for natural uranium. Soil samples subjected to plutonium, strontium and gamma spectral analyses showed no detectable buildup of these activities in the off-site environment.
\end{abstract}

\section{Introduction}

The Lawrence Livermore Laboratory is located about 50 miles southeast of San Francisco in the I,ivermore-Amador Valley. Shielded from the ocean by the western hills, the valley has a warm, dry climate. Annual rainfall is about 14 inches and occura primar the winter monthe in connection with Pacific storms. Surface water drainage from the valley is from east to west thrcugh various arroyos, with outflow near Sunol in the southwestern corner of the valley. Prevailing winds are from the west and southwest during April through September and from the northeast during the remainder of the year.

The Livermore Laboratory occupies an area of one square mile, situated approximately 3 miles east of Livermore. Site 300, a high explosives test area, is located 8 miles southwest of Tracy in sparsely populated hills of the Diablo range which separates the Livermore and San Joaquin Valleys. The population of 
Livermore is approximately 40,000 and the Livermore-Amador Valley population is estimated at 80,000 .

Agriculture is still an important activity in the valley although new housing developments and light industries are rapidly absorbing a sizable portion of the rural landscape. Roses, grain, grapes, hay, cattle, and sheep are the major agricultural products.

An environmental surveillance program is continually being conducted by the Laboratory in order to detect any increase in environmental radioactivity above natural background levels as a result of Laboratory operations. The progxam includes the col'ection of airborne particulates, soil, water, sewer effluent, milk, and vegetation samples. These samples are analyzed for gross radioactivities as well as for the activity of specific radionuclides of interest. In addition, the terrestrial background radiation is measured at numerous locations in the vicinity of the Livermore Laboratory by means of thermoluminescent detectors.

The results of the analyses are provided in this report. When appropriate for the sake of brevity and clarity only the maximum and average concentrations are given. Error limits, when included, only reflect the uncertainties in the analyses at the $68 \%$ confidence level due to counting statistics.

\section{Environmental Levels of Radioactivity-Livermore Laboratory}

\section{ATMOSPHERIC RADIOACTIVITY}

The concentrations of various airborne radioactive substances were measured at 16 air sampling stations situated throughout the Livermore Valley. Their locations are shown in Figs, 1 and 2. The six samples located on the Laboratory perimeter use 80 square-inch Whatman filters. The average sampling rate is $25 \mathrm{cfm}$. The remaining samplers, located off-site, use 36 square-inch HV-70 filters and operate at an average now rate of $4 \mathrm{cfm}$. These sampling stations are situated in such a mainer that a significant release of airborne particulate radioactivity from the Laboratory would be detected regardless of the local meteorology at the time of the release. Filters are changed weekly during the winter months and twice weekly during the summer to avoid excessive mass loading. An automatic radiation detection system with gas flow proportional detectors is used to determine gross alpha and beta activities deposited on the filters. The filters are also assayed for gamma emitting radionuclides by means of a specially designed ent ironmental system using a $\mathrm{Ge}(\mathrm{Li})$ detector equipped with Compton suppression. ${ }^{1}$

No gross alpha activity above the $0.001 \mathrm{pCi} / \mathrm{m}^{3}$ detection limit was observed on the filters. The gross beta activities averaged over three-month periods are shown in Table 1 for each sampling location. A significant fraction of the beta activity deposited on the filters is due to global fallout produced by nuclear weapons tests and by cosmic-ray 


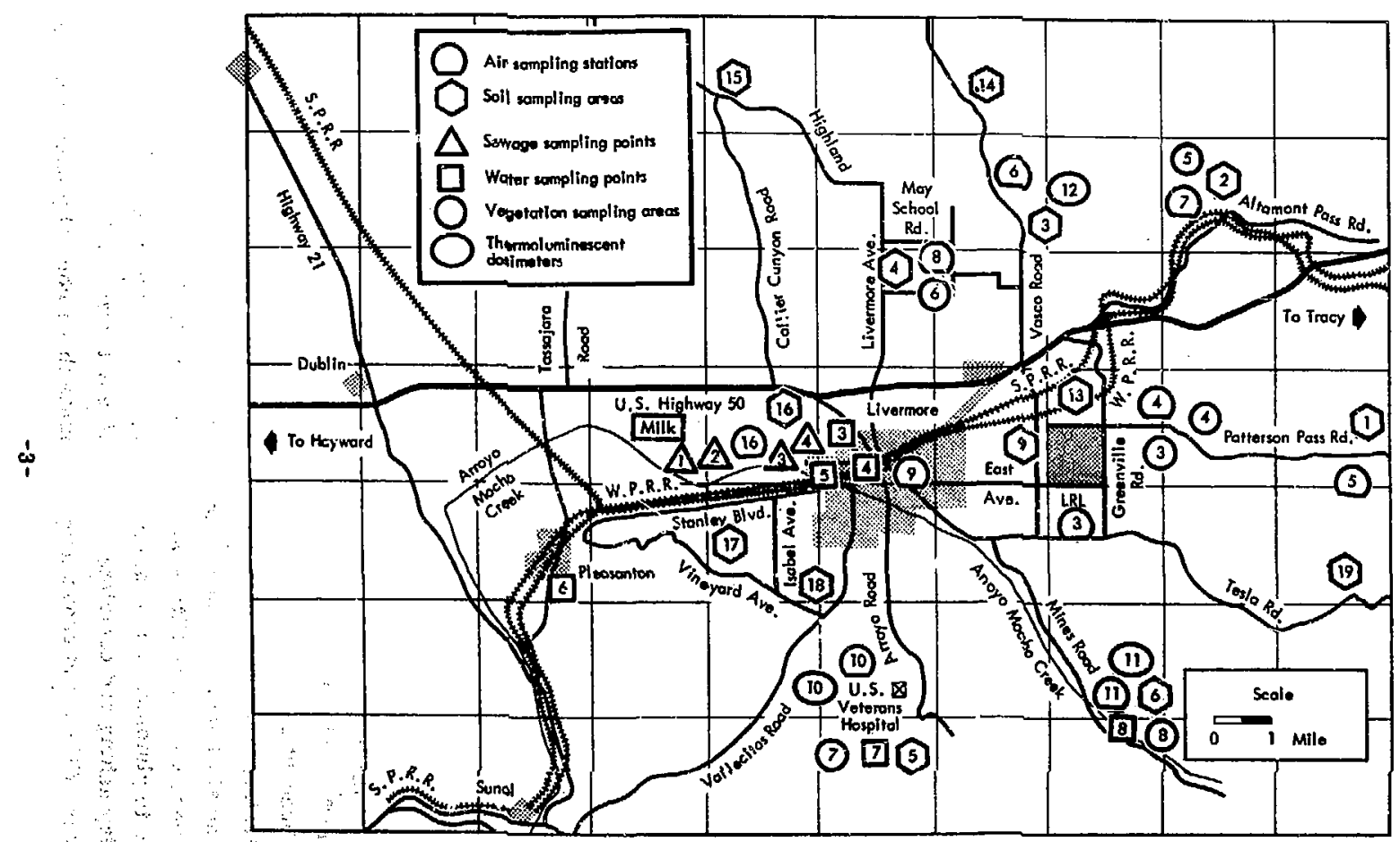

Fig. 1. Lawrence Livermore Laboratory off-site environmental sampling locations. 


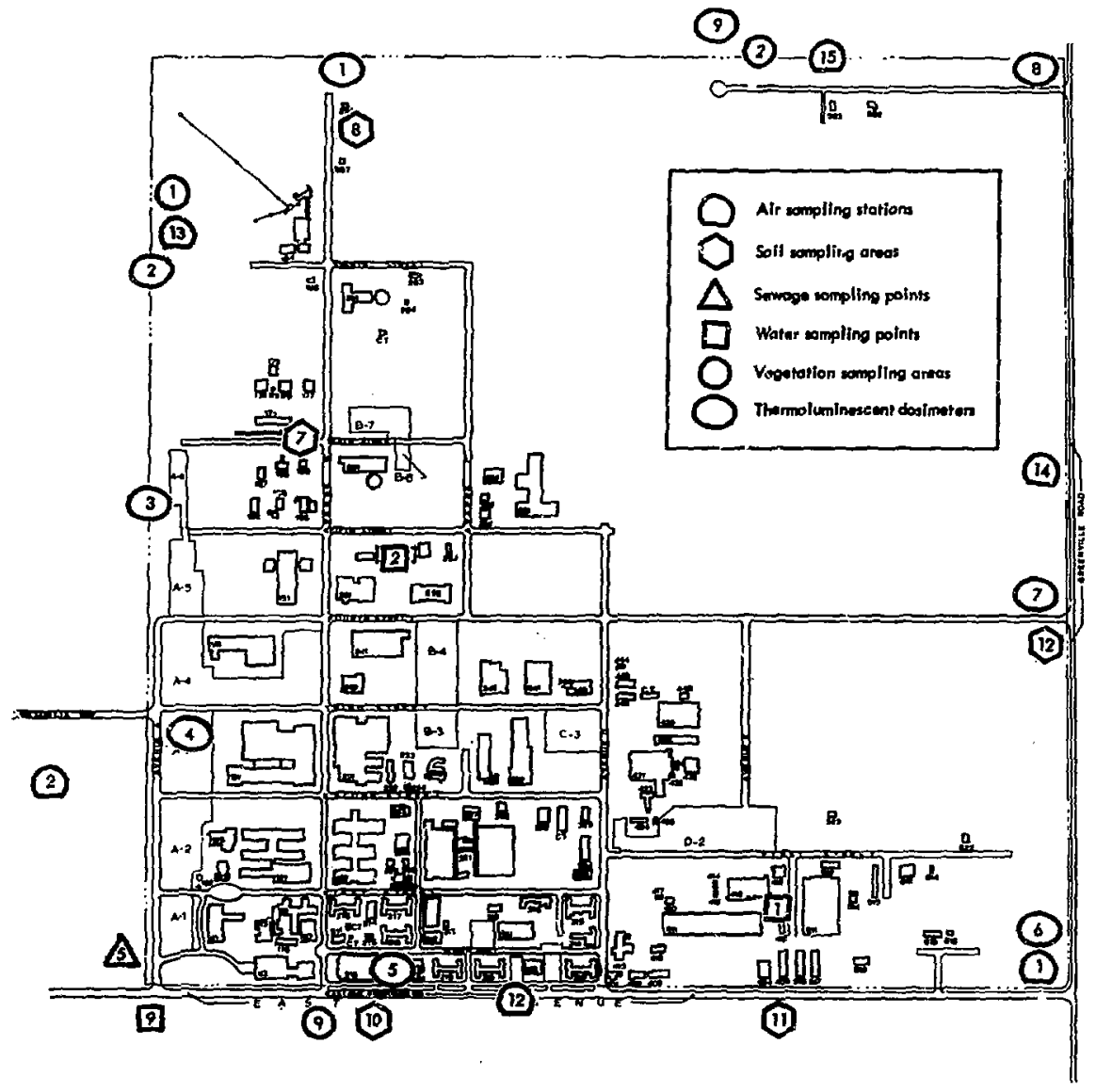

Fig. 2. Lawrence Livermore Laboratory on-Eite environmental sampling stations.

interactions with the atmosphere. This is Dhown in Table 2 which liats the activities of the more abundant gamma emitting nuclides in monthy composite samples collected by the six Laboratory perimeter samplers. These composite filters were also aubjected to plutonium and uranium analyses by dry ashing and complete dissolution of the futers and subsequent radiochemical separation of the elements. The plutonium was isolated by ion exchange techniques and counted by alpha spectrometry. The isotopic uranium analyses were performed by Inass spectrographic methods. The results are provided in Table 3 . Inspection of the data reveals that the relative activities of ${ }^{238} \mathrm{Pu}$ and ${ }^{239} \mathrm{Pu}$ approxtmate those normally observed in global 
Table 1. Gross airborne particulate beta activity within the Livermore valley $\left(\mathrm{pCl} / \mathrm{m}^{3}\right)$.

\begin{tabular}{cccccc}
\hline $\begin{array}{c}\text { Sampling } \\
\text { stations }\end{array}$ & \multicolumn{2}{c}{ January - March } & \multicolumn{2}{c}{ April - June } \\
\cline { 2 - 5 } Maximum & Average & Maximum & Average \\
\hline 1 & $0.45 \pm 1 \%$ & $0.10 \pm 3 \%$ & $0.24 \pm 1 \%$ & $0.18 \pm 2 \%$ \\
8 & $0.25 \pm 1 \%$ & $0.083 \pm 3 \%$ & $0.25 \pm 1 \%$ & $0.18 \pm 1 \%$ \\
4 & $0.15 \pm 6 \%$ & $0.073 \pm 9 \%$ & $0.17 \pm 3 \%$ & $0.13 \pm 4 \%$ \\
5 & $0.55 \pm 2 \%$ & $0.14 \pm 5 \%$ & $0.31 \pm 2 \%$ & $0.23 \pm 2 \%$ \\
6 & $0.34 \pm 2 \%$ & $0.084 \pm 8 \%$ & $0.26 \pm 2 \%$ & $0.16 \pm 3 \%$ \\
7 & $0.30 \pm 2 \%$ & $0.14 \pm 4 \%$ & $0.17 \pm 3 \%$ & $0.12 \pm 4 \%$ \\
8 & $0.051 \pm 12 \%$ & $0.031 \pm 19 \%$ & $0.16 \pm 3 \%$ & $0.12 \pm 4 \%$ \\
9 & $0.10 \pm 6 \%$ & $0.042 \pm 14 \%$ & $0.24 \pm 2 \%$ & $0.13 \pm 4 \%$ \\
10 & $0.35 \pm 2 \%$ & $0.098 \pm 6 \%$ & $0.22 \pm 3 \%$ & $0.18 \pm 3 \%$ \\
11 & $0.30 \pm 3 \%$ & $0.096 \pm 7 \%$ & $0.24 \pm 2 \%$ & $0.13 \pm 4 \%$ \\
12 & $0.30 \pm 2 \%$ & $0.073 \pm 9 \%$ & $0.19 \pm 3 \%$ & $0.12 \pm 4 \%$ \\
13 & $0.41 \pm 1 \%$ & $0.11 \pm 3 \%$ & $0.28 \pm 1 \%$ & $0.21 \pm 2 \%$ \\
14 & $0.33 \pm 2 \%$ & $0.10 \pm 3 \%$ & $0.28 \pm 1 \%$ & $0.19 \pm 1 \%$ \\
15 & $0.81 \pm 1 \%$ & $0.20 \pm 3 \%$ & $0.56 \pm 1 \%$ & $0.41 \pm 1 \%$ \\
16 & $0.38 \pm 1 \%$ & $0.097 \pm 3 \%$ & $0.26 \pm 1 \%$ & $0.19 \pm 2 \%$ \\
\hline
\end{tabular}

${ }^{a}$ See Fig. 1 for location of stations.

Table 2. Results of gamma-ray spectral measurements of Livermore perimeter air filters. (Activities in $\mathbf{p C} \hat{\mathbf{i}} / \mathrm{m}^{3}$ ).

\begin{tabular}{|c|c|c|c|c|c|c|c|c|}
\hline Month & ${ }^{144} \mathrm{Co}$ & ${ }^{14 l_{\mathrm{C}}} \mathrm{C}$ & ${ }^{125} \mathrm{Sb}$ & ${ }^{7} \mathrm{se}$ & ${ }^{105} \mathrm{Ru}_{\mathrm{u}}$ & ${ }^{106}{ }_{R u}$ & ${ }^{137} \mathrm{Cg}$ & ${ }^{85} \mathrm{Zr}$ \\
\hline Jenuars & $0.5 \times 10^{-3} \pm 3 \%$ & $2.9 \times 10^{-3} \pm 6 \%$ & $0.7 \times 10^{-4} \pm 16 \%$ & $4.7 \times 10^{-2} \neq 45$ & $3.3 \times 10^{-3} \neq 8 \times$ & $3.1 \times 10^{-3} \pm 25 \%$ & $8.4 \times 10^{-4} \pm 9 \times$ & $3.3 \times 10^{-3} \pm 4 \%$ \\
\hline Pebsuars & $1.4 \times 10^{-2} \neq 3 \pi$ & $1.2 \times 10^{-5} \pm 5 \%$ & $1.2 \times 10^{-3} \pm 205$ & $4.8 \times 10^{-2} \pm 57$ & $6.1 \times 30^{-9}=6 \%$ & $5.3 \times 10^{-3} \pm 26 \pi$ & $1.0 \times 10^{-3} \pm 127$ & $1.5 \times 10^{-3} \pm 5 n$ \\
\hline Meareh & $6.0 \times 10^{-2} \pm 1 \%$ & $1.5 \times 10^{-2} \pm 26$ & $2.4 \times 10^{-9} \pm 11 \%$ & $7.1 \times 10^{-2} \pm 4 \%$ & $2.2 \times 10^{-2} \pm 2 \pi$ & $1 . c \times 10^{-2}=98$ & $3.1 \times 17^{-3} \pm 5$ & $3.1 \times 10^{-2} \pm 15$ \\
\hline April & $5.5 \times 10^{-2} \pm 15$ & $1.3 \times 1.0^{-2} \pm 2 \times$ & $2.8 \times 10^{-3}+15 \%$ & $7.5 \times 10^{-2} \pm 5 \%$ & $1.4 \times 10^{-2} \pm 3 \%$ & $2.4 \times 10^{-2} \pm 12 \pi$ & $3.8 \times 10^{-3} \pm 6 \%$ & $9.6 \times 10^{-2} \pm 1 \%$ \\
\hline Mag & $1.2 \times 10^{-1} \pm 1 \%$ & $1.7 \times 10^{-2} \pm 25$ & $7.8 \times 10^{-3} \neq t \%$ & $1.1 \times 1 n^{-1} \pm 4 \times$ & $3.4 \times 10^{-2} \pm 8 \%$ & $4.1 \times 10^{-2} \pm 0 \times$ & $0.1 \times 10^{-3} \pm 56$ & $7.9 \times 10^{-9} \pm .4$ \\
\hline June & $6.2 \times 10^{-2} \neq 2 \%$ & $6.2 \times 10^{-3} \pm 6 \times$ & $3.2 \div 10^{-3} \pm 327$ & $1,6 \times 10^{-2} \neq 98$ & $1.2 \times 10^{-1} \pm 54$ & $2.7 \times 10^{-2} \pm 17 \%$ & $4.9 \times 10^{-3}+10 \%$ & $3.2 \times 10^{-2} \pm 2 \times$ \\
\hline
\end{tabular}

Table 3. Plutonium and uranium concentrations in Livermore perimeter air filters.

\begin{tabular}{|c|c|c|c|c|c|c|}
\hline \multirow[b]{2}{*}{ Month } & \multicolumn{2}{|c|}{ Activity $\left(\mathrm{pCl} / \mathrm{m}^{3}\right)$} & \multirow[b]{2}{*}{${ }^{238} \mathrm{Pu} /{ }^{238} \mathrm{Pu}$} & \multicolumn{2}{|c|}{$\operatorname{Mage}\left(n g / \mathrm{m}^{3}\right)$} & \multirow[b]{2}{*}{${ }^{235} \mathrm{U} /^{238} \mathrm{v}$} \\
\hline & ${ }^{2188} \mathrm{Pu}$ & ${ }^{288} \mathrm{Pu}$ & & $285 \mathrm{u}$ & $238 \mathrm{u}$ & \\
\hline Janux $r y$ & $3.4 \times 10^{-6} \pm 6 \%$ & $2.4 \times 10^{-5} \pm 3 \%$ & $1.4 \times 10^{-1}$ & $2.2 \times 10^{-4} \pm 27$ & $4.7 \times 10^{-2} \pm 1 \%$ & $4.7 \times 10^{-3}$ \\
\hline Eebruary & $8.3 \times 10^{-7} \pm 6 \%$ & $0.2 \times 10^{-6} \pm 9 \%$ & $0.0 \times 10^{-2}$ & $7.0 \times 10^{-5} \pm 1 \%$ & $1.0 \times 10^{-2} \pm 2 \%$ & $6.6 \times 10^{-3}$ \\
\hline March & $3.6 \times 10^{-5} \pm 6 \%$ & $3.4 \times 10^{-4} \neq 4 \%$ & $1.1 \times 10^{-1}$ & $1.3 \times 10^{-3} \pm 1 \%$ & $1.7 \times 10^{-1} \pm 1 \%$ & $7.6 \times 10^{-3}$ \\
\hline Aprll & $9.1 \times 10^{-6} \pm 7 \%$ & $7,9 \times 10^{-3} \pm 4 \%$ & $1.2 \times 10^{-1}$ & $2,5 \times 10^{-4} \pm 1 \%$ & $3.6 \times 10^{-2} \pm 2 \%$ & $6.8 \times 10^{-3}$ \\
\hline may & $5.7 \times 10^{-6} \pm 7 \%$ & $1.1 \times 10^{-4} \pm 4.4$ & $5.4 \times 10^{-2}$ & $6.3 \times 10^{-5} \pm 15$ & $1.0 \times 10^{-1} \pm 1 \%$ & $6.3 \times 10^{-3}$ \\
\hline
\end{tabular}


SOIL

fallout. Similarly the ${ }^{235} \mathrm{U} / \mathrm{f}^{23 \mathrm{E}_{\mathrm{T}}}$ ratio approximates that observed in natural uranium.

The weekly average beta activities on the air filters from all the Livermore sampling stations are shown in Fig. 3 . The well known spring increase in surface air activity levels due to enhanced transport of stratosphere air into the troposphere is verified by the data.

A soil sampling program has recently been initiated to determine the surface distribution of various radionuclides that have been deposited within the Livermore Valley as a result of global, fallout from atmospheric weapons tests as well as from possible Laborutory effluent discharges. A core sampling method was

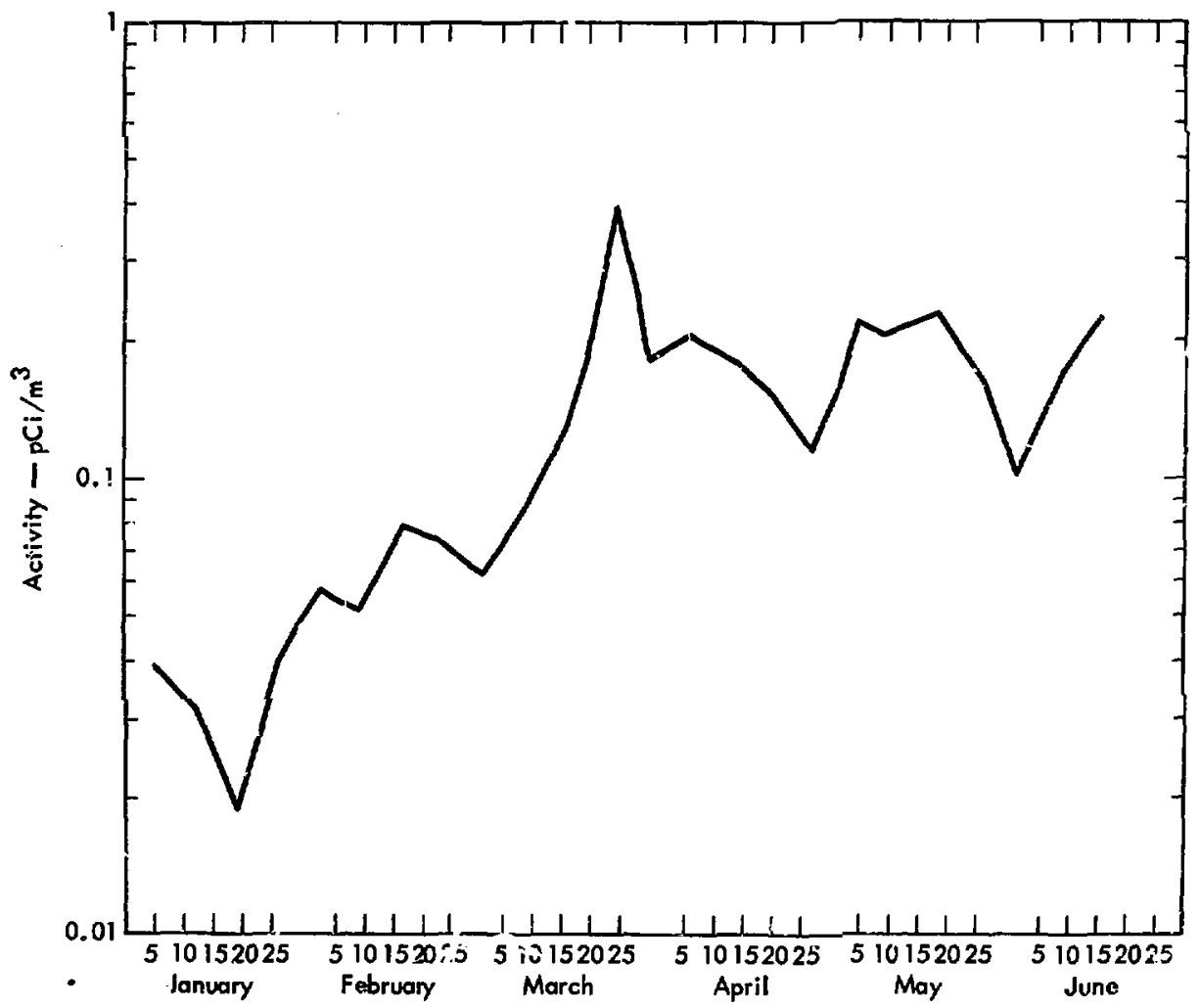

Fig. 3. Weekly average beta activity on air filters from Livermore sampling Itations. 
used to obtain the soil samples at various depths down to $20 \mathrm{~cm}$ for activity/depth profile studies. Each sample was collected over a surface area ranging between $250 \mathrm{~cm}^{2}$ to $1000 \mathrm{~cm}^{2}$ by means of combining a minimum of 10 separate cores obtained over a roughly $30 \mathrm{~m}^{2}$ area.

The samples were thoroughly dried and homogenized before undergoing analyses for radionuclides of interest. A minimum of 50 grams of soil were subjected to either the HASL acid leach method $^{2}$ or a somplete dissolution method for the analyrsis of ${ }^{238} \mathrm{Pu},{ }^{239} \mathrm{Pu}$, and ${ }^{90} \mathrm{Sr}$. Analysis of the leach residues from several samples for quality control purposes indicated that approximately $90 \%$ of the total plutonium activity in the samples was removed by this leach method. Gamma spectral analyses were made by placirg approximately $\mathbf{3 0 0}$ grams of soil on a $\mathrm{Ge}(\mathrm{Li})$ detector equipped with Compton surpression systems. ${ }^{1}$ These analyses provided quantitative data regarding the concentrations of ${ }^{13} \mathrm{Cs}$, ${ }^{144} \mathrm{Ce}$, and ${ }^{95} \mathrm{Zr}$ in Livermore soils.

The results of the analyses are provided in Table 4, and the sampling locatio.18 are shown in Fig. 4, The depth profiie studies sho:y that the radionuclides, including plutonium, do penetrate appreciably into the soil, probably as a resuit of leaching or mechanical mixing. Generally the activity in the $15-20-\mathrm{cm}$ layer is about a factor of 10 less than that in the top 1-cm layer, although wide variations may be observed in the data. $T$ ine resulting deposition concentrations are shown in Table 5. The higher activities shown at the on-site locations 2 to 7 are due to their close proximity to the area being used for solar evaporation of low-level radioactive waste liquids. At this time there is no evidence of any off-site contamination.

In adoition, soil samples consisting of the top 1-cm layer were collected quarterly in the Livermore Valley at the 19 sampling locations shown in Figs. 1 and 2. 'ihese samples were digested in a mixture of perchloric and nitric acids, evaporated to dryness, redissolved in hydrogen peroxide and plated onto stainless steel plates for gross alpha and gross beta counting. The average alpha activity of all the samples was $2.8 \pm 45 \% \mathrm{pCi} / \mathrm{g}$ with a high value of $4.7 \pm 35 \% \mathrm{pCi} / \mathrm{g}$. $\cdots$ beta activities exhibited an average value of $7.2 \pm 17 \% \mathrm{pCi} / \mathrm{g}$ with a maximum valu. of $13 \pm 12 \% \mathrm{pCi} / \mathrm{g}$. These activities are within the normal range for soil in the Livermore Vailey as determined by surveillance during previous year:

\section{LABORATORY SEWER EFFLUE:}

The liquid and solid effluent discharged through the Lab oratory sanitary sewer system is treated at the City of Livermore Sewage Treatment Plant. The iquid and sluc'ge are separated on enter ag this plant. The siudge passes into one of two digesters where it is broken down by bacterial action. Methane gas is evolved and burned, and the remaining sludge is released to large sludge ponds and retaintu for subsequent use as a soil conditioner. The purified water is used for irrigating the Livermore golf course and nearby agricultural land with the excess being discharged into the Los Positas Arroyo.

Sewage samples were collected daily at the Laboratory point of discharge into 
Table 4. Actipity levels of various radionuclides in soll (pCl/g).

\begin{tabular}{|c|c|c|c|c|c|c|c|}
\hline amilng & (em) & ${ }^{2 s} \boldsymbol{H}_{\mathrm{Pu}}$ & ${ }^{290} \mathrm{Pu}$ & $\operatorname{eo}_{\mathrm{Sr}}$ & ${ }^{137} \mathrm{c.}$ & $85_{\mathrm{Zr}}$ & $111 \mathrm{ce}$ \\
\hline \multirow[t]{3}{*}{1} & $0 .-0$ & & $2.7 \times 10^{-2} \pm 5 \%$ & $1.1 \times 10^{-1} \pm 18 \%$ & $1.2 \times 10^{-1} \pm 13 \%$ & & \\
\hline & $E-10$ & & $2.3 \times 10^{-3} \pm 10 \mathrm{H}$ & $8.2 \times 10^{-2} \pm 18 \%$ & $0.2 \times 10^{-2} \pm 21 \%$ & & \\
\hline & $10-18$ & & $5.5 \times 10^{-3} \pm 10 \%$ & $0.4 \times 10^{-2} \pm 208$ & $8.0 \times 10^{-2} \pm 244$ & & \\
\hline 3 & $0-15$ & $2,2 \times 10^{-3} \neq 2 \%$ & $3.4 \times 10^{-2} \pm 2 \%$ & $1.5 \times 10^{-1} \pm 7 \times$ & & & \\
\hline$t$ & a. Is & $1.8 \times 10^{-2} \pm 54$ & $1.0 \times 10^{-1} \pm 36$ & $1.4 \times 10^{-1}=14$ & & & \\
\hline - & $0-13$ & $0.8 \times 10^{-2} \pm 5 \%$ & $3.0 \times 10^{-1}=36$ & $1.0 \times 1 r^{-1} \neq 24$ & & & \\
\hline 8 & 0.15 & $2.7 \times 10^{-1} \pm 15$ & $0.8 \times 10^{-1} \pm 4 \pi$ & $1.1 \times 10^{-1} \pm 74$ & & & \\
\hline- & $0-16$ & $24 \times 10^{-3} \pm 5 x$ & $0.5 \times 10^{-3} \geq 8 \times 4$ & $1.4 \times 10^{-1} \pm 75$ & & & \\
\hline 7 & $0-15$ & $1.2 \times 10^{-3} \pm 3 \times$ & $1.3 \times 10^{-2} \neq 9 \%$ & $1.0 \times 10^{-1} \pm 4 \pi$ & & & \\
\hline D & $0-15$ & $1.3 \times 10^{-3} \pm 5$ & $0,6 \times 10^{-3}+34$ & $8,2 \times 10^{-2} \pm 28 \%$ & & & \\
\hline \multirow[t]{5}{*}{ - } & $0-1$ & & $1.0 \times 10^{-2}+14 x$ & $1,8 \times 10^{-1} \pm 13 x$ & $2.4 \times 10^{-1} \pm 8 \times$ & $4.5 \times 10^{-2}+206$ & $1.2 \times 10^{-1} \pm 365$ \\
\hline & $1-3$ & & $1.7 \times 10^{-9} \pm 12 \pi$ & $1.0 \times 10^{-1} \pm 20 \mathrm{n}$ & $3.1 \times 10^{-1} \pm 2 \pi$ & & \\
\hline & $B=10$ & & $3.2 \times 10^{-3}+30 \%$ & $1.0 \times 10^{-1} \pm 20 \%$ & $1.1 \times 10^{-1} \pm 16 \%$ & & \\
\hline & $10-18$ & & $2.3 \times 10^{-9} \pm 20 \pi$ & $5.5: 10^{-2} \pm 25 \%$ & $\leq 3,0 \times 10^{-2}$ & & \\
\hline & $13-20$ & & $6.4 \times 10^{-4} \pm 225$ & $1,8 \times 10^{-2} \pm 25 \%$ & & & \\
\hline \multirow[t]{5}{*}{10} & $0-1$ & & $6.8 \times 10^{-9} \pm 54$ & $1.8 \times 10^{-1} \pm 35$ & $8.1 \times 10^{-1} \pm 7 \%$ & $5.3 \times 10^{-2} \pm 17 x$ & $1.2 \times 10^{-1} \pm 5 \times$ \\
\hline & $1-5$ & & $3.0 \times 10^{-3}+5 \%$ & $1.0 \times 10^{-1} \pm 5 \%$ & $1.6 \times 10^{-1} \pm 11 \times$ & & \\
\hline & $3-10$ & & $3.3 \times 10^{-3} \pm 7 \pi$ & $10 \times 10^{-1} \pm 3 \pi$ & $1.7 \times n^{-1} \pm 13 n$ & & \\
\hline & $10-15$ & & $1.4 \times 10^{-3}+128$ & $5.0 \times 10^{-2} \pm 3 x$ & $5,2 \times \quad 2 \pm 20 x$ & & \\
\hline & $15-20$ & & $7.3 \times 10^{-4} \pm 195$ & $1.7 \times 10^{-2} \pm 5 \%$ & $8.6 \times 10^{-2} \pm 435$ & & \\
\hline \multirow[t]{5}{*}{$\mathbf{n}$} & $0-1$ & $1.0 \times 10^{-9} \neq 38 \%$ & $0.5 \times 10^{-3} \pm 74$ & & $2.8 \times 10^{-1} \pm 8 \%$ & $4.0 \times 10^{-2} \pm 27 \%$ & $1.2 \times 10^{-2} \pm 334$ \\
\hline & $1-3$ & $3.5 \times 10^{-1} \div 50 \%$ & $8,2 \times 10^{-3} \pm 5 \%$ & & $2.3 \times 10^{-1} \pm 100$ & & \\
\hline & $s-10$ & $7.7 \times 10^{-4} \pm 36 \pi$ & $7.7 \times 10^{-3} \pm 7 \%$ & & $9.2 \times 10^{-2} \neq 216$ & & \\
\hline & $10-15$ & $0.5 \times 10^{-1} \pm 28 \pi$ & $1.5 \times 10^{-2} \pm 0.6$ & & $3.9 \times 10^{-2} \pm 356$ & & \\
\hline & $15-20$ & $2.1 \times 10^{-4} \pm 88 \%$ & $4.5 \times 10^{-3} \pm 8 \%$ & & $53.0 \times 10^{-2}$ & & \\
\hline \multirow[t]{2}{*}{12} & $0-1$ & $0.8 \times 10^{-4}: 75$ & $8.2 \times 10^{-3} \pm 4 \%$ & $1.0 \times 10^{-1} \pm 28$ & $1.5 \times 10^{-1} \pm 16 \%$ & $6,0 \times 10^{-2} \pm 24 x$ & $9.8 \times 10^{-1} \pm 22 \%$ \\
\hline & $1-25$ & $1.0 \times 10^{-4} \pm 100$ & $2.7 \times 10^{-3} \pm 47$ & $6.7 \times 10^{-2} \pm 26$ & $5.4 \times 10^{-2} \pm 244$ & & \\
\hline \multirow[t]{2}{*}{13} & $0-1$ & $3.3 \times 10^{-4}+25 \%$ & $5.1 \times 10^{-3} \pm 48$ & $1,5 \times 10^{-1} \pm 2 \pi$ & $2.0 \times 10^{-1} \pm 11 \%$ & $1.1 \times 10^{-1}+128$ & $1.4 \times 10^{-1} \pm 487$ \\
\hline & $1 \cdot 15$ & $1.0 \times 10^{-4} \pm 100$ & $2.5 \times 10^{-3} \pm 17$ & $7.5 \times 10^{-2} \pm 27$ & $7.4 \times 10^{-2} \pm 174$ & & \\
\hline \multirow[t]{2}{*}{14} & $0-1$ & $2.3 \times 10^{-4} \pm 100$ & $7.1 \times 10^{-3} \pm 54$ & $1.8 \times 10^{-1} \pm 2 \pi$ & $2.0 \times 10^{-1} \pm 13 \%$ & $1.1 \times 10^{-1} \pm t 4 \%$ & $4.6 \times 10^{-1} \pm \mathrm{L6 \%}$ \\
\hline & $1-15$ & $6.3 \times 10^{-5} \pm 54 x$ & $3.8 \times 10^{-3} \pm 5 \%$ & $7.6 \times 10^{-2} \pm 2 \pi$ & & & \\
\hline
\end{tabular}

See Fig. 1 lor locuston of stations. 



月

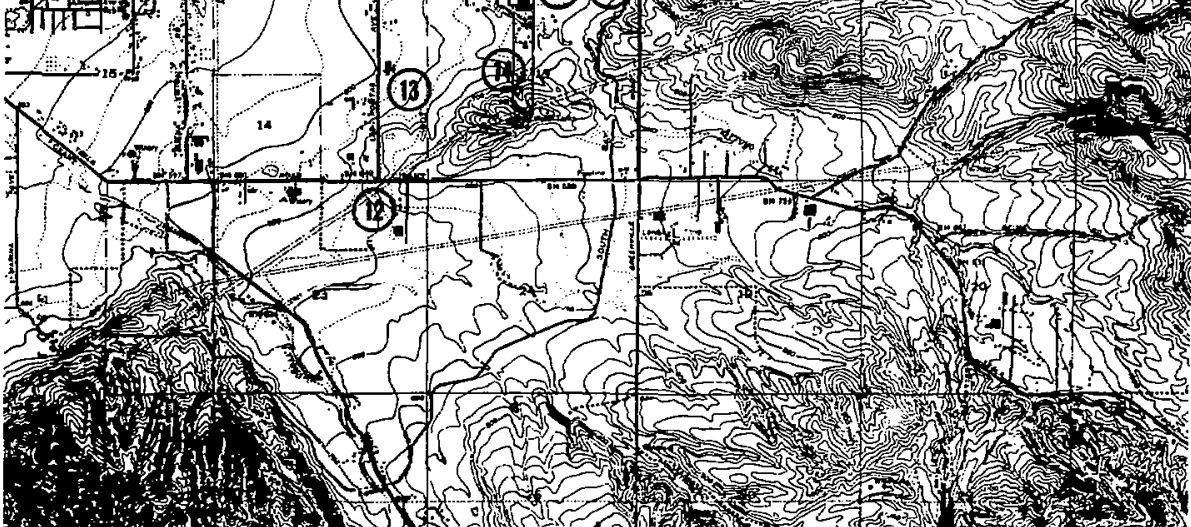

Fig. 4. Livermore Valley soil sampling locations. Location 1 (not shown) is about 5 miles west of the Laboratory. 
Table 5. Deposition levels of various radionuclides in soil (activities $\ln \mathrm{mCi} / \mathrm{km}^{2}$ ).

\begin{tabular}{ccccccc}
\hline $\begin{array}{c}\text { Sampling } \\
\text { stations }\end{array}$ & ${ }^{238} \mathrm{Pu}$ & ${ }^{239} \mathrm{Pu}$ & ${ }^{90} \mathrm{Sr}$ & ${ }^{137} \mathrm{CB}$ & ${ }^{95} \mathrm{Zr}$ & ${ }^{144} \mathrm{Ce}$ \\
\hline 1 & & 2.7 & 18 & 23 & \\
2 & 4.8 & 7.5 & 33 & & \\
3 & 3.4 & 22 & 31 & & \\
4 & 18 & 63 & 21 & & \\
5 & 56 & 180 & 23 & & \\
6 & 0.65 & 2.6 & 38 & & \\
7 & 1.2 & 3.7 & 29 & & \\
8 & 0.29 & 1.9 & 18 & & \\
9 & & 1.5 & 21 & 29 & 0.61 & 1.6 \\
10 & & 0.76 & 20 & 31 & 0.72 & 1.6 \\
11 & 0.16 & 2.6 & 19 & 26 & 0.54 & 0.23 \\
12 & 0.028 & 0.65 & 16 & 13 & 0.60 & 3.8 \\
13 & 0.024 & 0.57 & 17 & 17 & 1.3 & 1.6 \\
14 & 0.018 & 0.65 & 17 & &
\end{tabular}

See Fig. 1 for location of stations.

Table 6. Results of laboratory Bewer effluent monitoring.

\begin{tabular}{|c|c|c|c|c|c|c|c|c|c|c|}
\hline \multirow{3}{*}{$\frac{\text { Month }}{\text { Januery }}$} & \multicolumn{2}{|c|}{ Alphs activity (pCi/Aiter) } & \multicolumn{2}{|c|}{ Bete activity (pCi/liter; } & \multicolumn{2}{|c|}{ Tritlum actlvity (pCl/hiter) } & \multicolumn{4}{|c|}{ Mixed lodine (pcl/hiter) } \\
\hline & \multirow{2}{*}{$\frac{\text { High }}{26 \pm 14 \%}$} & \multirow{2}{*}{$\frac{\text { Average }}{7.2 \pm 29 \%}$} & High & Average & \multirow{2}{*}{$\frac{\text { High }}{2.3 \times 10^{5} \pm 1 \%}$} & \multirow{2}{*}{$\frac{\text { Average }}{2.9 \times 10^{4} \pm 3 \%}$} & \multicolumn{2}{|c|}{ High } & \multicolumn{2}{|c|}{ Average } \\
\hline & & & $160 \pm 2 \%$ & $54 \pm 5 \%$ & & & 1100 & $\pm 1 \%^{\mathrm{a}}$ & 74 & $\pm 5 \%$ \\
\hline Februsary & $11 \pm 18 \%$ & $4.7 \pm 50 \%$ & $120 \pm 2 \%$ & $42 \pm 11 \%$ & $1.2 \times 10^{4} \pm 5 \%$ & $5.9 \times 10^{3} \pm 25 \%$ & 33 & $\pm 10 \%$ & 17 & $\pm 62 \%$ \\
\hline March & $17 \pm 17 \%$ & $7.2 \pm 45 \%$ & $1400 \pm 1 \%$ & $200 \pm 4 \%$ & $6.7 \times 10^{4} \pm 4 \%$ & $8.6 \times 10^{3}+40 \%$ & 53 & $\pm 8 \%$ & 17 & $\pm 63 \%$ \\
\hline Apra & $19 \pm 16 \%$ & $4.8 \pm 31 \%$ & $130 \pm 3 \%$ & $39 \pm 5 \%$ & $3.4 \times 10^{4} \pm 13 \%$ & $9.1 \times 10^{3} \pm 20 \%$ & $\mathbf{5}$ & $\pm 50 \%$ & & $5 \pm 54 \%$ \\
\hline May & $10 \pm 18 \%$ & $5.0 \pm 20 \%$ & $\pm \mathbf{4 7}$ & $35 \pm 10 \%$ & $2.0 \times 10^{4} \pm 5 \%$ & $5.0 \times 10^{3} \pm 34 \%$ & 28 & $\pm 18 \%$ & & $\pm 45 \%$ \\
\hline June & $18 \pm 25 \%$ & $5.8 \pm 31 \%$ & $180 \pm 3 \%$ & $36 \pm 22 \%$ & $7.0 \times 10^{3} \pm 100$ & $3.4 \times 10^{3} \pm 23 \frac{4}{5}$ & 5.1 & $\pm 50 \%$ & & $\pm 50 \%$ \\
\hline
\end{tabular}

aThis value resulted from an individual who had been receiving an ${ }^{131}$ i medieal exposure.

the Livermore sewer system. These samples were prepared for alpha and beta counting by techniques similar to those used to prepare soil samples for the gross activity measurements. In addition, 1 milliliter of each gample was analyzed for tritium activity by direct liquid scintillation counting. A separate portion of each sample was subjected to inorganic iodine anaiysis by radiochemically geparating the fodine by a standard organic extraction and precipitation procedure.
The resulting precipitate was then beta counted. The regults of these ana'yses for each month are given in Table 6.

A portion of each of the daily samples was composited during each month. These monthly composite samples were subjected to ${ }^{90} \mathrm{Sr},{ }^{226} \mathrm{Ra}$, and ${ }^{228} \mathrm{Ra}$ analyses. The strontium determinations were performed by radiochemically separating the strontium activity from the aamples. After ${ }^{90} \mathrm{Sr} /{ }^{90} \mathrm{Y}$ equilibrium had been established, the ${ }^{90} \mathrm{Y}$ was 
separated for beta counting. The ${ }^{226} \mathrm{Ra}$ activities were obtained by collecting the ${ }^{222} \mathrm{Rn}$ released from the samples over a two week period. The radon gas was then counted in a $z$ ine sulfide scintillation Setector. The ${ }^{228} \mathrm{Ra}$, on the other hand, was radiochemically separated and beta counted. The results of the analyses are given in Table 7. Samples were also collected at the Livermore Sewage Treatment Plant to determine that no Iignificant build-up of radioactivity occurred at the plant. Weekly samples were collected from each digester and the aeration tani for gross radioactivity analyses. Approximately three samples per week were obtained of the liquid effluent discharged from the plant. These were analyzed for gross activity and tritium, and a monthly composite sample of the affluent was analyzed for ${ }^{90} \mathrm{Sr}$. The results of these analyses, averaged over one month periods, are given in Table 8 .
Table 7. Activities of ${ }^{90} \mathrm{Sr},{ }^{226} \mathrm{Ra}$, and $228 \mathrm{Ra}$ in monthly composite I.aboratory sewer samples.

\begin{tabular}{lccc}
\hline & \multicolumn{3}{c}{ Average activitieg (pCi/Aiter) } \\
\cline { 2 - 4 } Month & $90 \mathrm{~S}_{\mathrm{r}}$ & $226 \mathrm{Ra}$ & $228 \mathrm{Ra}$ \\
\hline January & $1.8 \pm 11 \%$ & $0.11 \pm 110 \%$ & $1.2 \pm 16 \%$ \\
February & $0.9 \pm 50 \%$ & $0.10 \pm 110 \%$ & $0.9 \pm 50 \%$ \\
March & $2.2 \pm 9 \%$ & $0.07 \pm 130 \%$ & $0.6 \pm 35 \%$ \\
April & $1.0 \pm 15 \%$ & $0.07 \pm 49 \%$ & $0.3 \pm 50 \%$ \\
May & $1.2 \pm 20 \%$ & $0.03 \pm 71 \%$ & $0.5 \pm 33 \%$ \\
\hline
\end{tabular}

\section{WATER}

Monthly samples were collected from various sources of water in the Livermore Valley to determine that no builchup of radioactivity occurred in local water supplies. These samples were analyzed for gross alpha, gross beta, and tritium activities by techniques similar to those listed for sewer samples. No sample showed an alpha astivity above the limit of detection of $1.2 \mathrm{pCi} /$ iter. The average

Table 8. Livermore Sewage Treatment Plant sampling results.

\begin{tabular}{|c|c|c|c|c|c|c|c|c|c|c|}
\hline \multirow{4}{*}{$\frac{\text { Month }}{\text { January }}$} & \multicolumn{8}{|c|}{ Gross alpha actlvily (pCl/hlter) } & \multicolumn{2}{|c|}{ Tritium aetivity (pot/fiter) } \\
\hline & \multicolumn{2}{|c|}{ Digesters } & \multicolumn{2}{|c|}{ Aeration tenk } & \multicolumn{4}{|c|}{ Efruent } & \multicolumn{2}{|c|}{ Elnuent } \\
\hline & High & Average & High & Average & & $\mathrm{HI}_{\mathrm{B}}^{\mathrm{h}}$ & & orage & High & Average \\
\hline & $280 \pm 20 \%$ & $250 \pm 23 \%$ & $57 \pm 19 \%$ & $43 \pm 23 \%$ & 22 & $\pm 50 \%$ & 13 & $\pm \mathbf{5 3} \%$ & $1.4 \times 10^{4} \pm 5 \%$ & $1.1 \times 10^{4} \pm 17 \%$ \\
\hline February & $230 \pm 24 \%$ & $160 \pm 28 \%$ & $29 \pm 28 \%$ & $27 \pm 44 \%$ & e0 & $\pm 50 \%$ & 26 & $\pm 66 \%$ & $4.1 \times 10^{3} \pm 50 \%$ & $9.6 \times 10^{9} \pm 50 \%$ \\
\hline March & $180 \pm 42 \%$ & $150 \pm 415$ & $4 \theta \pm 415$ & $39 \pm 37 \%$ & 32 & $\pm 50 \%$ & 14 & $\pm 61 \%$ & $2.4 \times 10^{5} \pm 3 \%$ & $4.3 \times 10^{4}=7 x$ \\
\hline Apral & $180 \pm 23 \%$ & $190 \pm 21 \%$ & $31 \pm 27 \%$ & $2 \theta \pm 28 \%$ & 11 & $\pm 50 \%$ & 54 & $\pm \mathbf{5 7 \%}$ & $8.0 \times 10^{3} \pm 14 \%$ & $4.2 \times 10^{3}+21 x$ \\
\hline May & $350 \pm 20 \%$ & $210 \pm 23 \%$ & $74 \pm 22 \%$ & $49 \pm 23^{\%}$ & 27 & $\pm 50 \%$ & 11 & $\pm 80 \%$ & $3.6 \times 10^{5}+24$ & $5.8 \times 10^{4} \pm 5 \times$ \\
\hline June & $510 \pm 13 \%$ & $260 \pm 18 \%$ & $52 \pm 21 \%$ & $48 \pm 22 \%$ & & $\pm 50 \%$ & & $\pm 64 \%$ & $1.8 \times 10^{3} \pm 50 \%$ & $1.7 \times 10^{3} \pm 50 \%$ \\
\hline
\end{tabular}

\begin{tabular}{|c|c|c|c|c|c|c|c|c|}
\hline \multirow[b]{2}{*}{ Month } & \multicolumn{6}{|c|}{ Grose beta activty (pCl/f(ter) } & \multicolumn{2}{|c|}{${ }^{80} \mathrm{~S} r$ actlvity (pCi/liter) } \\
\hline & \multicolumn{2}{|c|}{ Digesterg } & \multicolumn{2}{|c|}{ Acratton tank } & \multicolumn{2}{|c|}{ Efnuent } & Average & \\
\hline January & $1.4 \times 10^{3} \pm 5 \%$ & $530 \pm 8 \%$ & $60 \pm 4 \%$ & $49 \pm 5 \%$ & $48 \pm 15 \%$ & $17 \pm 32 \%$ & $0.5 \pm 50 \%$ & . \\
\hline February & $9.7 \times 10^{2} \pm 4 \%$ & $360 \pm 8 \%$ & $45 \pm 5 \%$ & $27 \pm 15 \%$ & $19 \pm 43 \%$ & $37 \pm 80 \%$ & $1.5 \pm 20 \%$ & \\
\hline March & $1.1 \times 10^{3} \pm 6 \%$ & $580 \pm 8 \%$ & $120 \pm 5 \%$ & $71 \pm 5 \%$ & $88 \pm 14 \%$ & $35 \pm 22 \%$ & $0.6 \pm 21 \%$ & \\
\hline April & $1.0 \times 10^{3} \pm 4 \%$ & $530 \pm 6 \%$ & $84 \pm 5 \%$ & $48 \pm 6 \%$ & $40 \pm 9 \%$ & $17 \pm 24 \%$ & $1.6 \pm 16 \%$ & \\
\hline May & $3.4 \times 10^{2} \pm 8 \%$ & $280 \pm 8 \%$ & $52 \pm 5 \%$ & $37 \pm 6 \%$ & $31 \pm 17 \%$ & $17 \pm 28 \%$ & $0.4 \pm 505$ & . \\
\hline June & $1.1 \times 10^{3} \pm 4 F_{0}$ & $880 \pm 7 \%$ & $41 \pm 5 \%$ & $36 \pm 6 \%$ & $17 \pm 24 \%$ & $15 \pm 25 \%$ & & \\
\hline
\end{tabular}


Table 9. Gross beta activities in Livermore water samples.

\begin{tabular}{cccc}
\hline Sampling & $\begin{array}{c}\text { January - March } \\
\text { Average gross } \\
\text { beta activity } \\
\text { (pCi/fiter) }\end{array}$ & $\begin{array}{c}\text { Sampling } \\
\text { stations }\end{array}$ & $\begin{array}{c}\text { Aprì - May } \\
\text { Average gross } \\
\text { beta activity } \\
\text { (pCi/liter) }\end{array}$ \\
\hline 1 & $4.3 \pm 41 \%$ & 1 & $2.1 \pm 50 \%$ \\
2 & $3.6 \pm 42 \%$ & 2 & $2.7 \pm 38 \%$ \\
3 & $2.9 \pm 34 \%$ & 10 & $4.7 \pm 19 \%$ \\
4 & $2.2 \pm 45 \%$ & 11 & $4.3 \pm 20 \%$ \\
5 & $2.7 \pm 36 \%$ & 12 & $4.6 \pm 20 \%$ \\
6 & $2.0 \pm 51 \%$ & 13 & $12 \pm 11 \%$ \\
7 & $3.1 \pm 32 \%$ & 14 & $3.1 \pm 26 \%$ \\
8 & $2.4 \pm 42 \%$ & 15 & $11 \pm 11 \%$ \\
9 & $2.6 \pm 39 \%$ & 16 & $1.8 \pm 50 \%$ \\
\hline
\end{tabular}

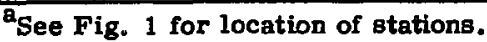

beta activitieg are given in Table 9.

Lccations 1 to 9 represent deep well water sources and commercial water sources of unknown origin. Locatiors 10 to 15 represent surface sources such as ponds (avallable to cattle), lakes and reservoirs. Lozation 16 is a deep well. The activities range over a factor of about 6 , with the higher activities generally being found in samples from surface sources. This is to be expected because of the intimate contact these sources have with the atmosphere, which containg large quantities of radioactivity produced by natural cosmic ray interactions and nuclear weapons detonations. The average tritlum activity in all of the samples was $4.0 \times 10^{3} \pm 29 \%$ with a maximum value of $1.1 \times 10^{4}$ $\pm 8 \%$ pCl/1iter.

\section{VEGETATION}

Gross samplea were collected from nire locations in the Livermore Valley dyring January, April, and May. Each sample was dried in ambient air for about one week and then pressed into a 5-inch diameter and 1-inch thick pellet weighing approximately 200 grams. This pellet was analyzed for various gamma emitting radionuclides by placing it between two $8 \times 4$ inch NaI(T1) crystals. A portion of each sample was also freeze-dried and the collected water was analyzed for tritium activity by direct scintillation ccunting. The concentrations of the gamma emitting radionuclides are listed in Table 10. The average tritium

Table 10. Radionuclide concentrations in vegetation samples.

\begin{tabular}{|c|c|c|c|}
\hline \multirow[b]{2}{*}{ Redionuclide } & \multicolumn{2}{|c|}{ Activity (pCl/g) } & \multirow{2}{*}{$\begin{array}{c}\text { Limit of } \\
\text { detestion } \\
\text { (pCi/g) }\end{array}$} \\
\hline & High & Average & \\
\hline$\overline{137} \mathrm{Ce}$ & 0.24 & 0.18 & 0.01 \\
\hline${ }^{106} \mathrm{Ru} /{ }^{106} \mathrm{Rh}$ & 0.64 & $\leq 0.34$ & 0.02 \\
\hline${ }^{144} \mathrm{Ce}$ & 2.4 & 1.4 & 0.02 \\
\hline${ }^{95} \mathrm{zr} / 95_{\mathrm{Nb}}$ & 1.4 & 0.63 & 0.01 \\
\hline 54 in & 0.04 & $\leq 0.02$ & 0.01 \\
\hline${ }^{\mathrm{z}} \mathrm{Be}$ & 2.4 & 1.8 & 0.01 \\
\hline${ }^{103} \mathrm{Ru}$ & $0.1 \mathrm{~s}$ & $\leq 0.07$ & 0.02 \\
\hline${ }^{125} \mathrm{Sb}$ & 0.04 & $\leq 0.02$ & 0.02 \\
\hline
\end{tabular}


activity of the freeze dried water was $2.5 \times 10^{4} \mathrm{pCi} /$ iter with a maximum of $2.7 \times 10^{5} \mathrm{pCi} /$ iter.

\section{MILK}

Samples were collected each month from dairies in the Livermore and Site 300 areas respectively. The Livermore Valley dairy is about 6 miles west of the Laboratory and the dairy in the Site 300 area is about 3 miles north of the Site. The samples were concentrated with a vacuum-operated, foam entrainment evaporator so that about 9 liters of whole millk were condensed to 2 liters. ${ }^{3}$ The resulting samples were gamme-counted in rlexiglass containera placed between two $8 \times 4$ inch Naí(T1) crystals. In addition, each sample was analyzed for tritium activity by counting 1 milliliter of the distillate directly in a standard liquid scintillation detector. The average activities of ${ }^{1: 17} \mathrm{Cs},{ }^{144} \mathrm{Ce}$, and tritium are ligted in Table 11.

\section{ACCIDENTAL RELEASE OF TRITIUM GAS}

Continuous air sampling is maintained on the stack effluent from the Gaseous Chemistry Bullding. On April 12, 1971, a small amount of tritium was released from this facllity. An extensive sampling program was conducted to evaluate the effects of the release on the environment. Vegetation, atmoopheric water vapor and water samples were collected and analyzed for tritium activity. The vegetation samples were freeze-dried and the collected water was subjected to scintillation counting. Other samples were counted directly in the same manner, Detectable activities were observed in some off-site vegetation and water vapor samples. The maximum activity in vegetation samples was $1.6 \times 10^{5} \mathrm{pCi} / \mathrm{Ltter}$ with the average activity of all the samples being $\leq 2.5 \times 10^{4} \mathrm{pCl} /$ iter. The atmoipheric water vapor samples ipdicated a maximum activity of $5.9 \times 10^{3} \mathrm{pCi} / \mathrm{m}^{3}$. and an average value of $2 \times 10^{3} \mathrm{pCl} / \mathrm{m}^{3}$. Thus, even the highest measured concentrations as well as the calculated. maximum credible ground level air concentretion that could hive resulted during passage of the tritium cloud were weli below the off-site maximum permigaible concentration for continuous exposure.

\section{EXTERNAL RADIATIOIJ MEASUREMENTS}

Terrestrial background radiation was measured with thermoluminescent dosimeters at the nine on-site locations shown in Fig. 2. The dosimeters, consisting of $\mathrm{CaF}_{2}$ : Dy chips, were placed

Table 11. Activities observed in milk samples (pCi/liter).

\begin{tabular}{|c|c|c|c|c|c|c|}
\hline & \multicolumn{2}{|c|}{${ }^{137} \mathrm{Cs}$} & \multicolumn{2}{|c|}{$144 \mathrm{Ce}$} & \multicolumn{2}{|c|}{$3_{\mathrm{He}}$} \\
\hline & High & Average & High & Average & Higi & Average \\
\hline Livermore diary & 9.1 & 4.9 & 18 & 9.8 & $1.0 \times 10^{5}$ & $2.4 \times 10^{4}$ \\
\hline Site 300 dairy & 5.6 & 3.5 & 13 & 3.9 & $6.7 \times 10^{3}$ & $5.2 \times 10^{3}$ \\
\hline
\end{tabular}




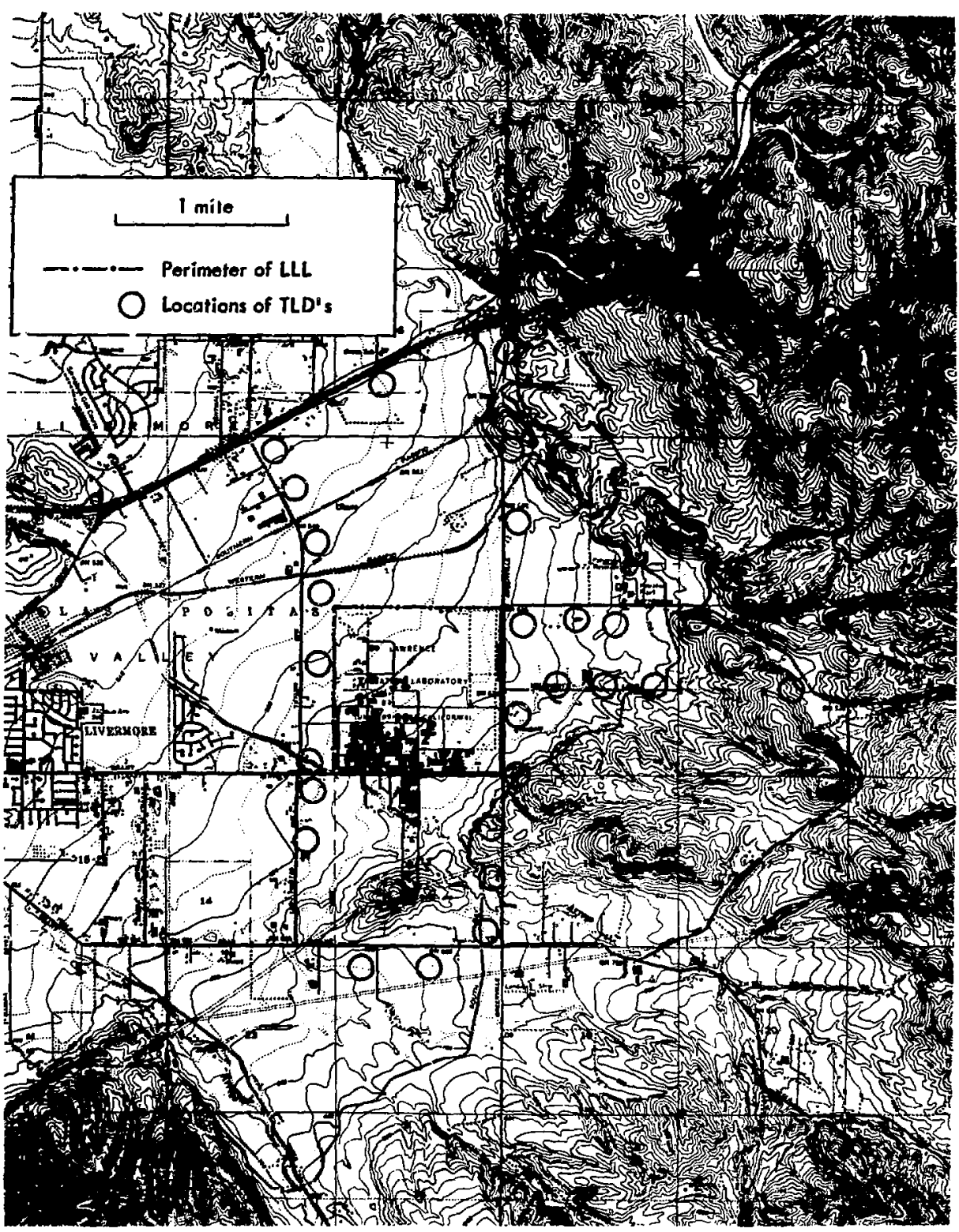

Fig. 5. Locations of thermolumineacent dosimeter locations in the vicinity of Lawrence Livermore Laboratory. 
about 1 meter above the ground and were exposed over a period of three months. The integrated exposures over the congecutive three-month periods are given in Table 12. The higher exposures measured at locations 1,3 , and 5 are undoubtedly due to their close proximity to a linear accelerator, a ${ }^{60}$ Co facility and a physics building, respectively.

Simllar measurements were made at 29 off-site locations (shown in Fig. 5) in the immediate vicinity of the Laboratory over the period of March 15 to June 15, 1871. The resulting exposures ranged from 7.9 to $14 \mathrm{mR}$ over the three-month perlod with a median of $11 \mathrm{mR}$. The frequency distribution of the exposures is shown in Fig. 6.
Table 12. Terrestrial background radiation levels measured during three-month periocis (map/3-mo).

\begin{tabular}{ccc}
\hline Stations & $\begin{array}{c}\text { January } \\
\text { March }\end{array}$ & $\begin{array}{c}\text { April } \\
\text { June }\end{array}$ \\
\hline 1 & 13 & 13 \\
2 & & 12 \\
3 & 18 & 14 \\
4 & 10 & 12 \\
5 & 41 & 18 \\
6 & 10 & 12 \\
7 & 10 & 10 \\
8 & 10 & 11 \\
8 & 10 & 10 \\
\hline
\end{tabular}

${ }^{a}$ See Fig. 2 for location of itations.

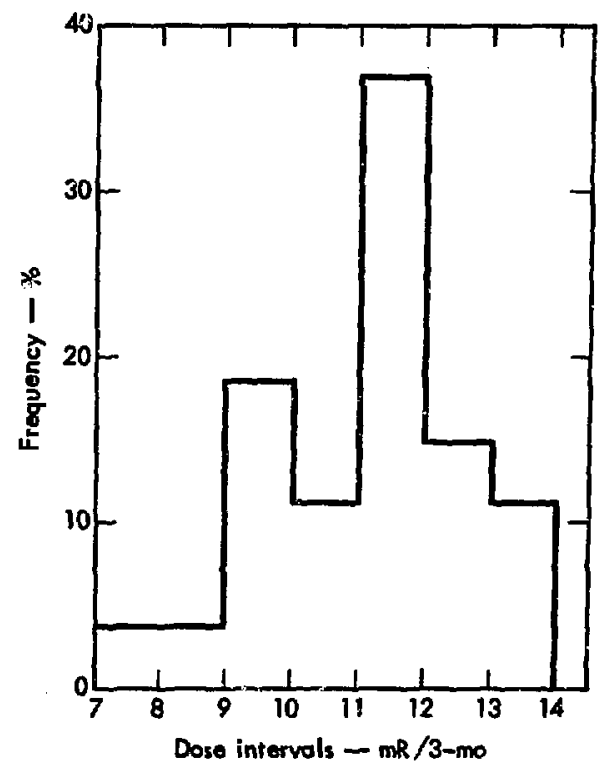

Fig. 6. Frequency diatribution of TLD measurements from the locutions shown in Fig. 4. 


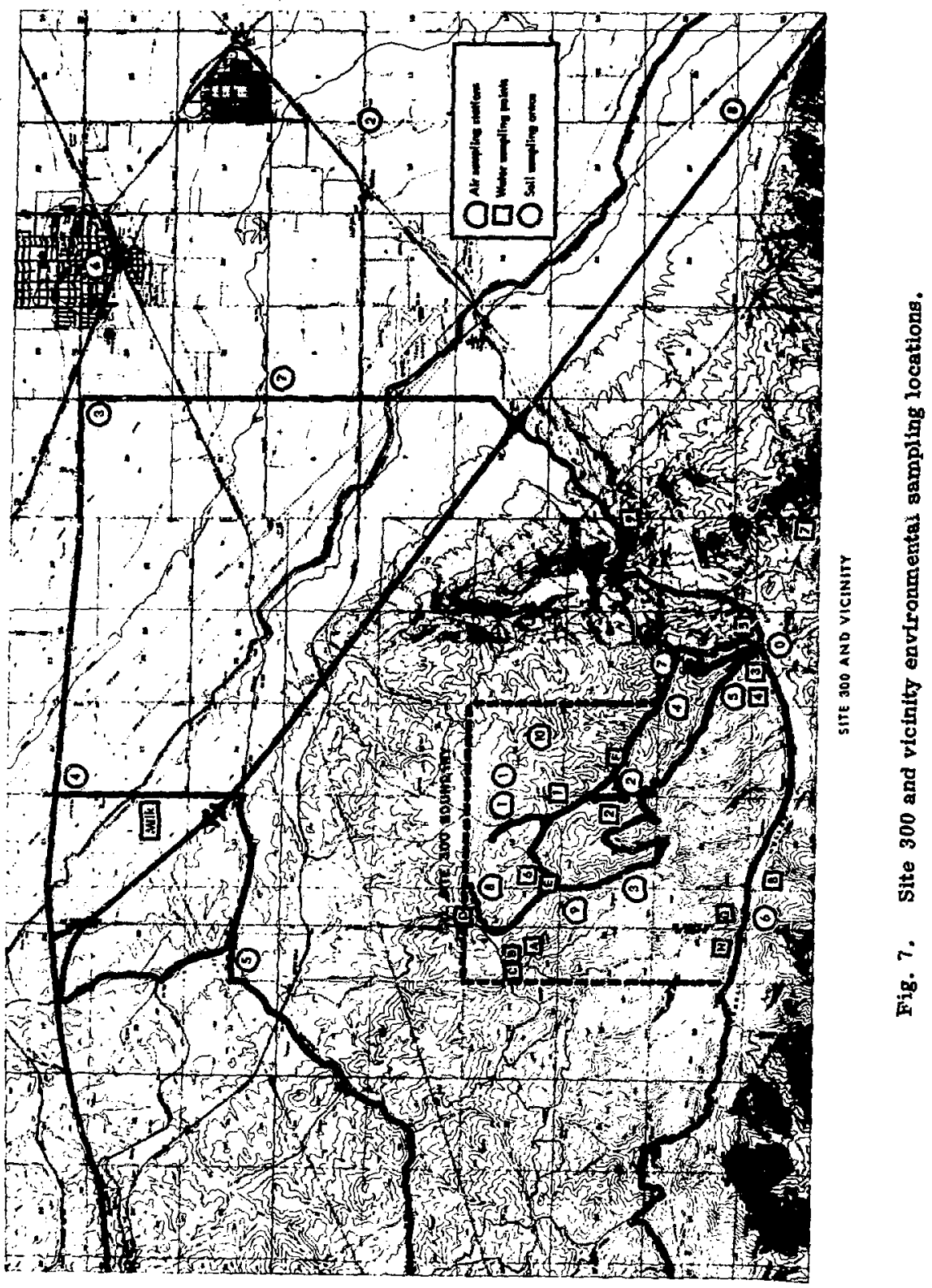




\section{Environmental Levels of Radioactivity-Site $\mathbf{3 0 0}$}

\section{ATMIOSPHERIC RADIOACTIVITY}

The concentrations of various alrborne radioactive substances were measured continuously at 11 air sampling stations located as shown in Fig. 7, Ten of the samplers were located within the boundaries of Site 300 because electric power is not avallable off-site. The remaining sampler is located in Tracy, the primary population center of concern. The on-site samplers are operated continuously at about $25 \mathrm{cfm}$, and have Whatmon filters while the sampler in Tracy has HV-70 filters and operates at a flow rate of about $4 \mathrm{cfm}$. The filters are changed weekly during the winter months and twice weeldy during the summer to avoid excessive mass loading. The filters are analyzed in a similar manner to that previously described for filters used in the Livermore Valley.

No gross alpha activity above the $0.001 \mathrm{pCi} / \mathrm{m}^{3}$ detection limit was observed on these filters. The gross beta activities, averaged over three-month periods, are shown is Table 13 for each sampling location. The average activities are slightly higher than those measured in the Livermose Valley. Gamma apectral measurements made on monthly composite samples of the on-site filters reveal measurable quantities of various gammaemitting radionuclides as may be seen in Table 14. The activity levels are essentially identical with those measured in the Livermore Valley. The results of leotopic plutonium and uranium anslyses, performed by the techniques described previously, are provided in Table 15.

Table 13. Aixborne particulate activity around LRL Site 300.

\begin{tabular}{|c|c|c|c|c|}
\hline \multirow{2}{*}{$\begin{array}{l}\text { Sampling } \\
\text { stationg }\end{array}$} & \multicolumn{2}{|c|}{$\begin{array}{c}\text { January - March } \\
\text { Gross beta activity } \\
\left.\text { (pCi/m } 1 \mathrm{~m}^{3}\right)\end{array}$} & \multicolumn{2}{|c|}{$\begin{array}{c}\text { April - June } \\
\text { Gross beta activity } \\
\left.\text { (pCi } / \mathrm{m}^{3}\right)\end{array}$} \\
\hline & Maximum & Average & Maximux & Average \\
\hline 1 & $0.42 \pm 1 \%$ & $0.090 \pm 2 \%$ & $0.33 \pm 1 \%$ & $0,26 \pm 1 \%$ \\
\hline 2 & $0.40 \pm 1 \%$ & $0.095 \pm 3 \%$ & $0.34 \pm 1 \%$ & $0.22 \pm 1 \%$ \\
\hline $\mathbf{3}$ & $0.33 \pm 1 \%$ & $0.086 \pm 3 \%$ & $0.29 \pm 1 \%$ & $0.20 \pm 1 \%$ \\
\hline 4 & $0.18 \pm 2 \%$ & $0.065 \pm 3 \%$ & $0.30 \pm 1 \%$ & $0.23 \pm 1 \%$ \\
\hline 5 & $0.43 \pm 1 \%$ & $0.090 \pm 2 \%$ & $0.27 \pm 1 \%$ & $0.20 \pm 1 \%$ \\
\hline 6 & $0.42 \pm 2 \%$ & $0.12 \pm 5 \%$ & $0.31 \pm 2 \%$ & $0.23 \pm 2 \%$ \\
\hline 7 & $0.38 \pm 1 \%$ & $0.089 \pm 4 \%$ & $0.32 \pm 1 \%$ & $0.21 \pm 1 \%$ \\
\hline 8 & $0.27 \pm 1 \%$ & $0.077 \pm 3 \%$ & $0.29 \pm 1 \%$ & $0.24 \pm 1 \%$ \\
\hline 9 & $0.65 \pm 1 \%$ & $0.13 \pm 2 \%$ & $0.45 \pm 1 \%$ & $0.33 \pm 1 \%$ \\
\hline 20 & $0.44 \pm 1 \%$ & $0.11 \pm 2 \%$ & $0.39 \pm 1 \%$ & $0.29 \pm 1 \%$ \\
\hline 11 & $0.28 \pm 1 \%$ & $0.10 \pm 2 \%$ & $0.61 \pm 1 \%$ & $0.37 \pm 1 \%$ \\
\hline
\end{tabular}

Q See Fig. 7 for location of etaitona. 
Table 14, Results of gamma-ray spectral measuizements of Site 300 air filters (pCi/m ${ }^{3}$ ).

\begin{tabular}{|c|c|c|c|c|c|c|c|c|}
\hline Menth & $144 \mathrm{ce}$ & istce & $125_{50}$ & ${ }^{7} \mathrm{BP}$ & ${ }^{109} \mathrm{Ru}_{\mathrm{Ru}}$ & ${ }^{106} \mathrm{Au}$ & ${ }^{137} \mathrm{ca}$ & ${ }^{85} \mathrm{Zr}_{\mathrm{r}}$ \\
\hline & $3 \times 10^{-3}+23$ & $6 \times 10^{-3} \pm 7 \%$ & $5 \times 10^{-4} \pm 124$ & $.5 \times 10^{-2}+5 \%$ & $.0 \times 10^{-3} \pm 75$ & & $0.3 \times 10^{-4} \pm 5 \mathrm{k}$ & \\
\hline Fobruery & $1.2 \times 10^{-3} \pm 2 \%$ & $3.0 \times 10^{-3} \pm 4 x$ & $9.1 \times 10^{-4} \pm 14 \%$ & $4.0 \times 10^{-2} \pm 4 x$ & $5.5 \times 10^{-3} \pm 45$ & $3.8 \times 10^{-3} \pm 10 \%$ & $2.2 \times 10^{-3} \pm 74$ & $6.3 \times 10^{-3}=27$ \\
\hline Lireh & $4.0 \times 10^{-2} \pm 15$ & $3.5 \times 10^{-2} \pm 2 x$ & $2.2 \times 10^{-3} \neq 10 n$ & $7.6 \times 10^{-2} \pm 37$ & $2.2 \times 10^{-2} \pm 25$ & $1.5 \times 10^{-2} \pm 85$ & $3.9 \times 10^{-3} \pm 4 x$ & $2.8 \times 10^{-2}=1 \%$ \\
\hline Aprll & $3,0 \times 10^{-2} \pm 16$ & $8.2 \times 10^{-3} \pm 2.3$ & $2.0 \times 10^{-3}=28$ & $5.2 \times 10^{-2} \pm 14$ & $1.6 \times 10^{-2} \pm 36$ & $8.1 \times 10^{-3} \pm 105$ & $2.8 \times 10^{-3} \neq 8 \%$ & $2.9 \times 10^{-2} \pm 1 \%$ \\
\hline 10 & $1.0 \times 10^{-1} \neq 15$ & $1.4 \times 10^{-2} \pm 7 x$ & $5,8 \times 10^{-3} \leqslant 7 \%$ & $1.0 \times 10^{-1} \pm 35$ & $2,6 \times 10^{-2}=26$ & $4.3 \times 10^{-2} \pm 5 h$ & $7.5 \times 10^{-9} \pm 37$ & $6.1 \times 10^{-3} \neq 18$ \\
\hline on & $2.4 \times 10^{-2}=195$ & $0.0 \times 10^{-3} \pm 34$ & $1.0 \times 10^{-9} \pm 135$ & $6.0 \times 10^{-2} \pm 5 x$ & $1,3 \times 10^{-2} \pm 34$ & $\therefore 4 \times 10^{-2} \pm 34$ & $4.8 \times 10^{-3} \pm 84$ & $1.0 \times 10^{-2} \pm 18$ \\
\hline
\end{tabular}

Table 15. Plutonium and uranium concentrations bi Site 300 air fulters.

\begin{tabular}{|c|c|c|c|c|c|c|}
\hline \multirow[b]{2}{*}{ Month } & \multicolumn{2}{|c|}{ Activity $\left(\mathrm{pCi} / \mathrm{m}^{3}\right)$} & \multirow[b]{2}{*}{${ }^{238}{ }_{\mathrm{Pu}}{ }^{23{ }^{30}} \mathrm{Pu}$} & \multicolumn{2}{|c|}{$\operatorname{Mase}\left(\mathrm{ng} / \mathrm{m}^{3}\right)$} & \multirow[b]{2}{*}{${ }^{235} v \digamma^{238} v$} \\
\hline & ${ }^{238} \mathrm{Pu}$ & ${ }^{299} \mathrm{Pu}$ & & $235 \mathrm{v}$ & ${ }^{238} \mathrm{U}$ & \\
\hline Jenuary & $3.5 \times 10^{-6} \pm 6 \%$ & $2.7 \times 10^{-5} \pm 3 \%$ & $1.3 \times 10^{-1}$ & $1.8 \times 10^{-3} \pm 2 \%$ & $9.3 \pm 2 \%$ & $2.0 \times 10^{-3}$ \\
\hline February & $3.8 \times 10^{-6} \pm 6 \%$ & $3.1 \times 10^{-5} \pm 3 \%$ & $1.2 \times 10^{-1}$ & $1.5 \times 10^{-4} \pm 2 \%$ & $5.4 \times 10^{-2} \pm 2 \%$ & $2.8 \times 10^{-3}$ \\
\hline Barch & $8.2 \times 10^{-6} \pm 7 \%$ & $9.5 \times 10^{-5} \pm 4 \%$ & $6.6 \times 10^{-2}$ & $3.4 \times 10^{-4} \pm 1 \%$ & $8.3 \times 10^{-2} \pm 1 \%$ & $4.1 \times 10^{-3}$ \\
\hline Aprn & $4.8 \times 10^{-6} \pm B \times$ & $5.7 \times 10^{-5} \pm 4 \times$ & $7.2 \times 10^{-2}$ & $1.9 \times 10^{-3} \pm 1 \%$ & $0.0 \times 10^{-1} \pm 1 \%$ & $2.1 \times 10^{-3}$ \\
\hline Phing & $4.5 \times 10^{-6} \pm 7 \%$ & $3.4 \times 10^{-5} \pm 48$ & $6.1 \times 10^{-2}$ & $2.5 \times 10^{-4} \pm 4 \%$ & $6.5 \times 10^{-2} \pm 4 \%$ & $3.8 \times 10^{-3}$ \\
\hline
\end{tabular}

The relative abundance of ${ }^{238} \mathrm{Pu}$ to ${ }^{239} \mathrm{Pu}$ is approximately that expected in global fallout. The uranium content of airborne debris, on the other hand, is greatly depleted relative to that of natural uranium and the concentrations are at times aignificantiy greater than those measured in the Livermore Valley. This is not unexpected in view of the sizable quantities of depleted uranium that hare been expended over the years 28 a result of the high explosive detonations at the site. However, chese concentrations are nevertheless far lower than the current concentration guide levels set forth in AECM 0524.

The weekly average gross beta activities on the air filters are shown in Fig. 8. Again, the spring increase in surface air activity is evident.

\section{WATER}

Monthly samples were collected from on-site wells which supply water to the site and from various on-site streams and ponds. The locations of these sources are shown in Fig. 6. No sample showed an alpha activity above $1.2 \mathrm{pC}$ / $/$ iter, the limit of detection. The average beta activities are shown in Table 16. Locations 1 to 7 represent deep-well water sources and locations 8 and 9 represent creek sources. The activities were similar to those observed within the Livermore Valley.

An additional number of samples were collected twice a week from on-site springs and ponds and composited over two-month periods. These composite samples were analyzed for tritium 


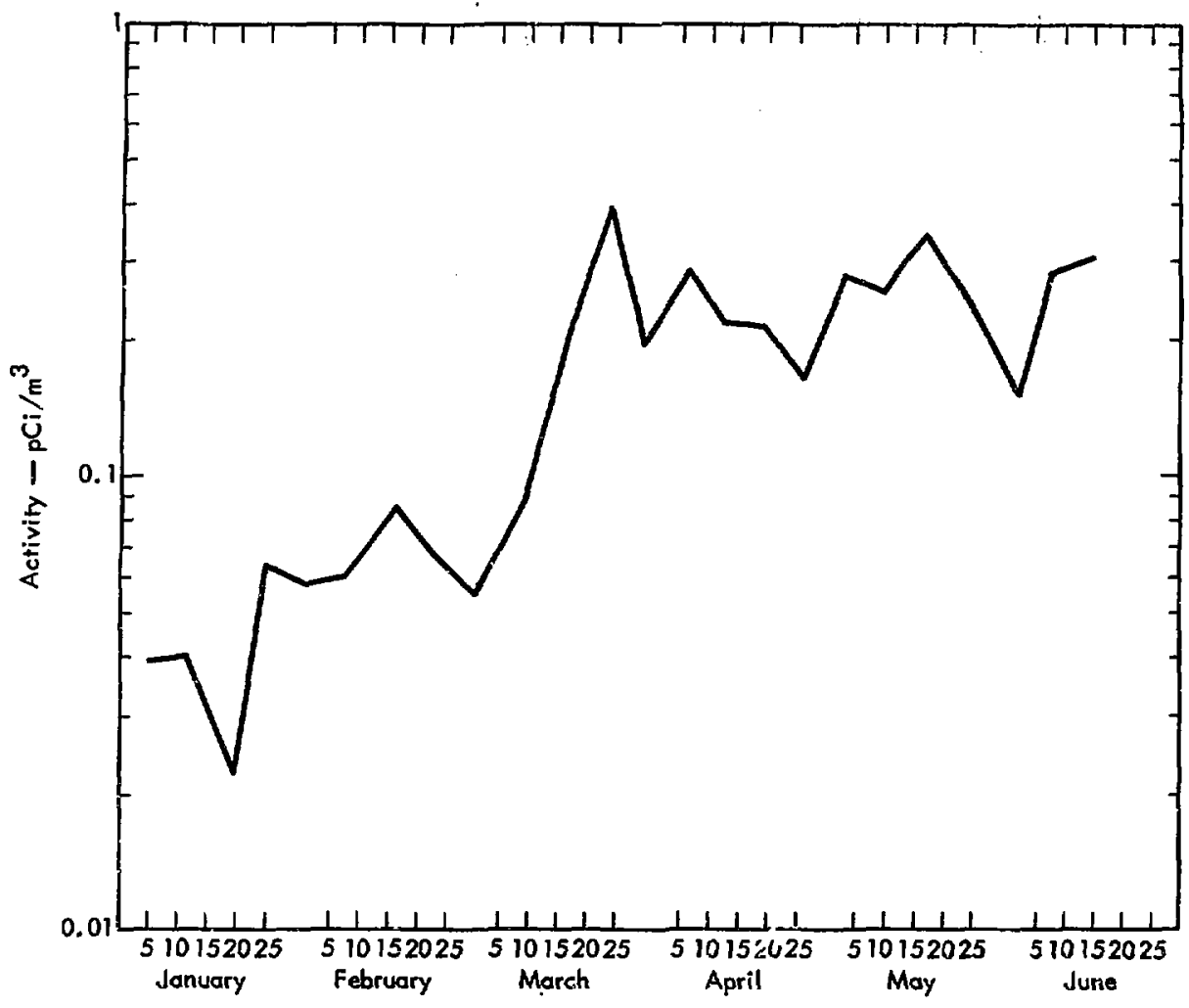

Fig. 3. Weekly average beta activity of air filters from Site 300 sampling stations.

Table 16, Average gross beta activities in Site 300 water samples (pCi/hiter).

\begin{tabular}{ccc}
\hline $\begin{array}{c}\text { Sampling } \\
\text { stations }\end{array}$ & January-March & Apri1-Mas \\
\hline 1 & $5.5 \pm 36 \%$ & $3.5 \pm 40 \%$ \\
2 & $11 \pm 17 \%$ & $4.8 \pm 30 \%$ \\
3 & $8.7 \pm 20 \%$ & $6.6 \pm 22 \%$ \\
4 & $5.9 \pm 34 \%$ & $4.1 \pm 32 \%$ \\
5 & $4.8 \pm 19 \%$ & $5.2 \pm 27 \%$ \\
6 & $6.2 \pm 26 \%$ & $4.6 \pm 32 \%$ \\
7 & $4.0 \pm 49 \%$ & $4.6 \pm 32 \%$ \\
8 & $8.2 \pm 20 \%$ & $11 \pm 16 \%$ \\
9 & $4.8 \pm 31 \%$ & $3.4 \pm 41 \%$
\end{tabular}

${ }^{\mathrm{a}}$ See Fig. 7 for location of stations. activities. The samples containing low tritium activities were racuum distilled, electrolytically enriched and analyzed by liquid scintillation counting. The results are shown in Table 17 . Inspection of the results reveals that all the activities, except for those in samples collected from sources $E$ and F, are within the normal fluctuations observed during previous sampling periods. Sources $E$ and $F$, which are springs, exhibit unusually high activities. However, no explanation is available regarding these activities since the 
Table 17. Tritium activities in Site 300 water Bamples (pCi/liter).

\begin{tabular}{|c|c|c|c|}
\hline $\begin{array}{l}\text { :inmpling } \\
\text { scatlongs }\end{array}$ & Janumry-Fctrugity & March-Aprll & May-June \\
\hline A & $3.1 \times 10^{2}: 10 \%$ & & \\
\hline $\mathbf{B}$ & $3.7 \times 10^{2} \pm 54 \pi$ & & \\
\hline C & $2.4 \times 10^{2} \pm 27 \%$ & $3.4 \times 10^{2}+7 \%$ & $4.1 \times 10^{2}+15 \%$ \\
\hline () & $2.6 \times 10^{2} \pm 218$ & & \\
\hline $\mathbf{E}$ & $6.0 \times 10^{5} \pm 17$ & $8.2 \times 10^{4} \pm 1 \%$ & $6.1 \times 10^{5} \pm 1 \%$ \\
\hline $\mathbf{F}$ & $3,8 \times 10^{1} \pm 36 \%$ & $4.1 \times 10^{1} \pm 22 \%$ & $2,8 \times 10^{5} \pm 2 \%$ \\
\hline $\mathbf{G}$ & $1.2 \times 10^{1} \pm 85 \%$ & $7.7 \times 10^{2} \pm 18 \%$ & $1.5 \times 10^{2} \pm 330 \%$ \\
\hline H & $2.0 \times 10^{2}+11 x$ & $5.0 \times 10^{2} \pm 225$ & $1.5 \times 10^{3} \pm 24 x$ \\
\hline
\end{tabular}

origins of the springs are fresently unknown.
SOIL

Soil samples were collected quarterly at the nine on- and off-site locations shown in Fig. 6. Only the top 1-cm layer was collected for analysis of gross alpha and gross beta activities. The average alpha activity of all the samples was $3.5 \pm 41 \% \mathrm{pCi} / \mathrm{g}$ with a maximum value of $5.1 \pm 33 \% \mathrm{pCi} / \mathrm{g}$. The beta activities indicated an average value of $7.5 \pm 17 \%$ with a high of $8.5 \pm 15 \% \mathrm{pCi} / \mathrm{g}$.

\section{Summary}

An environmental surveillance program was conducted in the Livermore Valley and Site 300 areas to ascertain the effect of the Laboratory's operations on the environment. Samples of airborne particulates, soil, water, sewage, milk, and regetation were collected and analyzed for gross radioactivity as well as for speciffe radionuclides of interest. The gross alpha and beta activities in airborne particulates, soil, water, and sew age samples were similar to those measured during the past year. Gamma spectral measurements of particulate debris collected by on-site air samplers revealed measurable activities of the typical gamma emitters present in global fallout. The relative activities of ${ }^{238} \mathrm{Pu}$ to ${ }^{239} \mathrm{Pu}$ in debris deposited on the filters were similar to those observed in global faliout, however, isotopic uranium analyses indicate the uranlum contained in the particulates collected on the air filters at Stte 300 was depleted with respect to that for natural uranium. This is un- doubtedly due to the expenditure of relatively large quantities of depleted uranium in high explosive detonations at Site 300 .

Livermore Valley soil samples, subjected to plutonium, strontium and gamma spectral analyses, revealed some on-site contamination in the vicinity of the area being used for solar evaporation of radioactive liquids, but no off-site contamination was indicated.

Milk and vegetation samples revealed no gamma-emitting radionuclides other than those present in global fallout. Their activities were similar to those observed during previous reporting Feriods.

The stack sampling program indicated a small amount of tritium did escape accidentally into the environment from the Gaseous Chemistry Building, however, on- and off-site tritium concentrations in atmospheric water vapor, vegetation and water samples collected downwind from the source were well below MPC levels. 
Thus, the radioactivity within the environment remained below the appropriate concentration guide levels listed in AEC Manual Chapter 0524. 


\section{Appendix}

\section{Environmental Activity Guide Levels}

The Standards for Radiation Protection (AEC Manual Chapter 0524, issued $11 / 8 / 68)$ state that if there is a mixture in air and water of radionuclides whose identity and concentrations are unknown, the average activity should not exceed the following values:

1. Air (controlled area)

$6 \mathrm{pCi} / \mathrm{m}^{3}$

2. Air (uncontrolled area)

$0.02 \mathrm{pCi} / \mathrm{m}^{3}$

3. Water (controlled area)

$400 \mathrm{pCi} /$ liter

4. Water (uncontrolled area)

$30 \mathrm{pCi} /$ iter

If it is known that alpha emitters and ${ }^{227}$ Ac are not present, the following guide values may be used to determine the permissible average activity:

5. Air (controlled area) $30 \mathrm{pCi} / \mathrm{m}^{3}$

6. Air (uncontrolled area) $1 \mathrm{pCi} / \mathrm{m}^{3}$

If it is known that ${ }^{129} \mathrm{I},{ }^{226} \mathrm{Ra}$, and ${ }^{228} \mathrm{Ra}$ are not present, the following values may be used:
7. Water (controlled area)
$3000 \mathrm{pCi} /$ liter
8. Water (uncontrolled area)
$100 \mathrm{pCi} /$ iter

The air and water samples are subjected to gross alpha and gross beta measurements. The average annual alpha activities may not exceed those listed under points 1 through 4 above. Since the alpha emitters have been accounted for in the gross alpha measurements, and the assumption is made that ${ }^{129} \mathrm{I},{ }^{227} \mathrm{Ac},{ }^{226} \mathrm{Ra}$, and ${ }^{228} \mathrm{Ra}$ are not present in the samples, the annual average gross beta activities of the samples may not exceed the activities listed under points 5 through 8 above. The assumption that ${ }^{129}{ }_{\text {I, }}$ ${ }^{227} \mathrm{Ac},{ }^{226} \mathrm{Ra}$, and ${ }^{228} \mathrm{Ra}$ are not present in air and water samples is reasonable in view of the minute quantities of these radionuclides available at the Laboratory. AEC Manual Chapter 0524 also states that the average tritium activities in off-site water samples may not exceed $3 \times 10^{6}$ pCi/liter.

Since analyses for ${ }^{129} \mathrm{I},{ }^{226} \mathrm{Ra}$, and ${ }^{228} \mathrm{Ra}$ activities are made on sewer effluent samples, the average monthly alpha and beta activities of these samples should not exceed the guide value of $360 \mathrm{pCi} /$ iter listed under point 7 above, and the tritium activity should not exceed $10^{8}$ pCi/liter.

The annual external whole body radiation dose to workers in controlled areas may not exceed $5 \mathrm{rem}$; while that to an individual in an uncontrolled area may not exceed $500 \mathrm{mrem}$. An average annual dose of $170 \mathrm{mrem}$ may not be exceeded for a group of individuals in an uncontrolled area. 


\section{References}

1. P. L. Phelps, K, O. Hamby, B. Shore and G. D. Potter, "A Ge(Li) Gamma Ray Spectrometer for High Sensitivity and Resolution for Biological and Environmental Counting," Advances in Chemistry No. 93 (Radionuclides in the Environment), American Chemical Society, 1970.

2. Manual of Standard Procedures, J. H. Harley, Ed., U.S. A. E. C. Health and Safety Laboratory Rept. NYO-4700.

3. J. R. Gaskill, "Vacuum-Operated, Foam-Entrainment Milk Evaporator," Fazards Cuntrol Progress Report No. 22, Lawrence Radiation Laboratory, Livermore, Rept. ITCRL-14534 (1965). 
